\title{
Noise and Housing
}

$\mathrm{T}$

HE great interest which is being displayed at the present time in quiet housing is reflected in two reports which have reached us : the first, on the "Hygiene of Housing", from an international commission of the Health Organisation of the League of Nations ; the other, on the "Construction of Flats for the Working Classes" (H.M. Stationery Office. 1s. net), from a Departmental Committee of the Ministry of Health. Both reports deal with various scientific and other aspects of the housing question, and are in general harmony as to the steps which should be taken in relation to the environmental problem of noise and its bearing on the amenities of housing.

The League of Nations Commission, under the chairmanship of Dr. G. W. C. Kaye, collated the experiences of a number of countries in lessening the nuisance of noise in many circumstances. The report directs attention to the significance of town planning by public or private authorities, with the view of locating dwellings in quiet areas, and securing the co-operation of industrialists in the lay-out of noisy plant. Not only external planning but also the interior planning of dwellings must be given close attention, so that, for example, bedrooms are allocated to the quietest rooms. Then again, dwellings may be insulated against external or internal noise or vibration by sound-proof walls, double windows, composite floors, suspended ceilings, resilient floor coverings, and sound-absorbent surfacings for walls and ceilings. Above all, noises should be reduced or isolated at the source; some countries have resorted to legal enactments and restrictions, but as regards others, research, education and the force of public opinion are more likely to be helpful. Among aggressively disturbing interior noises, particularly for flat dwellers, are powerful loud-speakers, hissing water taps and noisy sanitary fittings. Quieter motorvehicles would be a boon for those who live and try to sleep in dwellings situated in busy thoroughfares. The report quotes standards of noise-level which are considered desirable and practicable in different classes of rooms in various locations, together with standards of noise opacity of walls and floors for airborne and impact noises respectively.

The report of the Ministry of Health Committee, under the chairmanship of Sir George Humphreys, is on much the same general lines in its references to questions of acoustics. There is an appendix dealing with noise in working-class flats, which was prepared for the information of the Committee by the National Physical Laboratory and the Building Research Station. The Committee is impressed with the value of composite structures in arresting sound trans. mission, though it appreciates that the basic principles involved are not yet fully established. The Committee awaits the expeditious prosecution of research into the effects of specific forms of discontinuity in structural systems, and the provision of acoustic data for the different units of construction, not omitting, of course, the all-important matter of comparative cost.

\section{Association between Nematodes and Insects}

$\mathrm{M}^{\mathrm{s}}$ R. PROSPER BOVIEN contributes an important paper (written in English) on the above subject, in the Videns Kabelige Ueddelelseer fra Dansk naturhistorisk Forening, 101, 1937, which has only recently come to hand. His investigations relate to the family Anguillulidæ, which may become associated with insects in various ways. From a survey of the literature, and his own investigations, the author concludes that these nematodes and insects may be associated in four different ways. (1) Symbiotic association, such species living in the frass or tunnels of wood-inhabiting beetles. Other species live in the nests of ants or termites. The prevalence of a special larval stage ("Dauerlarve" of Fuchs) has been ascertained in some instances. These larvæ may be carried externally, for example, under the elytra of beetles, loosely adhering or pro. tected by a 'cocoon'. In some cases they may invade the gut, pharyngeal glands or the hæmocœl of the host. (2) Species found in dung and decaying vegetation which may pass through larval stages carried by insects loosely attached to the exoskeleton or firmly adhering as 'cysts'. Others have endoparasitic larvæ affecting insects. (3) There are also species which occur as actual parasites in the body-cavity of insects where reproduction takes place. (4) Species which combine parasitic and saprozoic types of behaviour.

Among the life-cycles studied by this author, special mention may be made of that of Heterotylenchus aberrans gen. et sp. nov. which is parasitic in the onion fly (Hylemyia antiqua) and of two new species of Neoaplectana which are abundantly present in larvæ of Bibionid flies. It is believed that the number of species with "Dauerlarven" is much larger than has been supposed. Their extraordinary power of resistance is commented upon and mention is made of finding living larvæ of Aphelenchoides in chrysanthemum leaves which had been kept for five years in a drawer in a laboratory. Among flies of the family Psychodidæ, up to 50 per cent were found to carry "Dauerlarven" of Rhabditis dubia sp.n. which are lodged externally like tightly fitting rings in the intersegmental furrows of the abdomen. When placed in dung, which harbours a rich population of Psychodidx, these larvæ developed into adults in a few days. The paper is one of more than ordinary interest, commended to the notice of zoologists as well as to the specialist. 